\title{
Tectonostratigraphic Evolution of the Brage Fault Zone, Norwegian North Sea
}

\author{
Adiotomre E. E. \\ Department of Geology, Delta State UniversityP.M.B. 1, Abraka, Nigeria
}

\begin{abstract}
This study investigates the tectonostratigraphic evolution of the Brage fault zone and suggests the fault is initially composed of six geometric segments that exert primary control on the general architecture of synrift stratigraphy.The hard linkage of these segments during Draupne times resulted in the obvious bend or jog that characterize the Brage fault trace. Isochron maps show isolated depocentres that are fault-parallel and in the hanging-wall of the Brage fault and other intrabasinal faults (Brage East and Brage Far West faults). The development of a major through-going Brage fault zone in Early Kimmeridgian-Ryazanian times resulted in a more open and continuous hanging-wall depocentre as accommodation creation became more uniform along fault strike. The Brage East and the Far West faults were intermittently active in the rift event and exhibits alternating activity with the Brage fault. The pronounced thickening of the lower Heather and upper Heather seismic stratigraphic units towards the Brage fault shows that the Brage fault was more active than the other intrabasinal faults. A pronounced fault parallel wedge-like geometry characterizes these units and is the result of a decrease in displacement along strike from the centre towards the tips of the fault. The findings of this study are consistent with those of other workers in the Norwegian North Sea and suggest that progressive linkage of initially isolated segments characterize the fault growth. The activity that alternates between the Brage fault and the Brage East fault also suggests that stress feedback between ruptures was probably an important mechanism controlling fault growth.
\end{abstract}

Keywords: Brage fault, fault growth, geoframe, Norwegian North Sea, synrift.

\section{Introduction}

The Brage area is located to the east of the Viking graben, which is a major structural element in the Norwegian North Sea sedimentary basin (Fig. 1) [1].Many fault segments and large basin-bounding normal faults occur in the Norwegian North Sea. These faults exert primary control on extension, subsidence, basin geometry and stratigraphy $[2,3,4,1]$. The Brage East fault formed in the Permo-Triassic and represented the western bounding fault of the full-graben. With the intersect of the footwall to the west of the Brage East fault by a west dipping Brage fault in the Jurassic, a narrow remnant of the older footwall remains to form the Brage Horst. The rest of the Permo-Triassic syn and post-rift successions lies beneath the Jurassic half-graben of the Oseberg Fault-Block [1].

The along strike variability of fault segment displacements with the greatest displacement at centre, and monoclines at the fault tips have profound effects on the overall stratigraphic architecture, rate of subsidence and migration patterns of depocentres of rift basins $[5,6,7]$. Accommodation in extensional settings is primarily control by the tectonic subsidence in the hanging walls of normal faults, and as a result, the synrift stratigraphy records the displacement history of normal faults $[8,9,10,11]$.

Previous workers, in the Norwegian North Sea Sedimentary Basin, focussed on normal faults evolution, and its control on synrift stratigraphy, in the areas to the west (Statfjord) and east (Oseberg) of Late Jurassic Viking Graben $[12,13,11]$. As a result, comprehensive data is available for the Statfjord East fault and Oseberg fault on the west and east of the Viking Graben. Although, it is documented that these faults grew from the linkage of a number of shorter fault segments, and the growth of the faults controlled the distribution and character of synrift sediments $[14,15,11]$, such generalisation cannot be extended to the Brage area. Considering the wide variability in the accumulated movement on fault segments that reportedly affects overall stratigraphy and depocentres migration in rift basins, it is imperative that the Brage fault is study in detail. This research studies the normal faults of the Brage area in the Norwegian North Sea and unravels how the faults grew and the effect of the fault growth on synrift packages. 


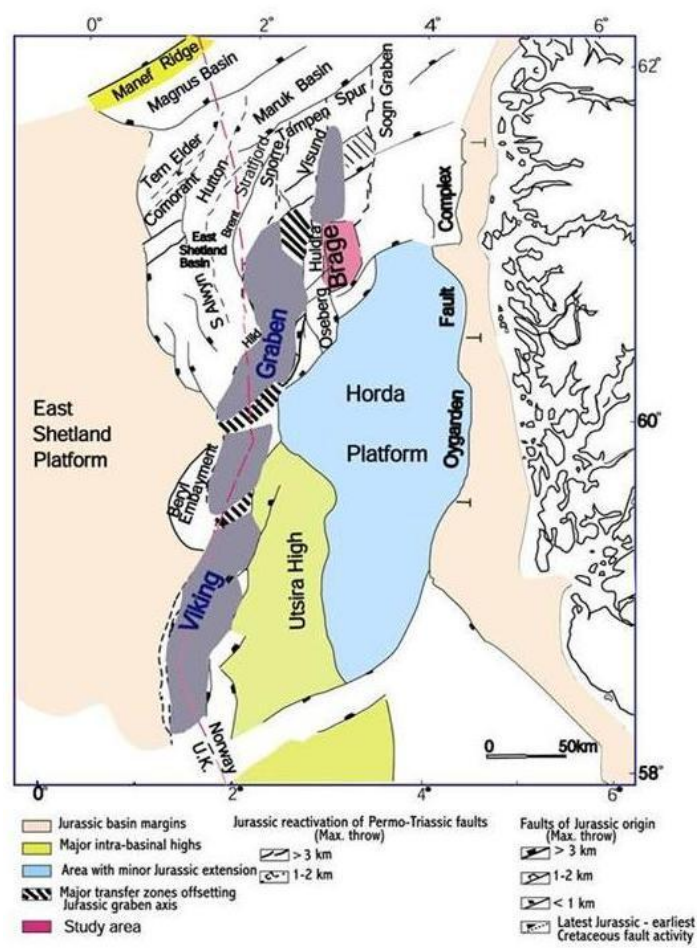

Fig. 1 - Map of the northern North Sea showing main structural elements and location of the study area (after Faerseth, 1996).

\section{Norwegian North Sea Sedimentary Basin}

The Norwegian North Sea sedimentary basin is a fault-bounded N-S trending extended crust that is about 170$200 \mathrm{~km}$ wide. The basin is bound in the east and west by the mainland of western Norway and east Shetland Platform respectively [1]. Large normal faults that trend N-S, NE-SW and NW-SE occur within the basin; the faults developed during the Permo-Triassic extension and reactivated by the Jurassic stretching episode [2, 16, $3,4]$. In the northern part of the Norwegian North Sea, Viking and SognGrabens occur as a system of discrete rift segments and makes up the Jurassic rift [1]. The tectono-stratigraphic evolution of the northern North Sea is class into three main stages; namely pre-rift, main rift or syn-rift and post rift stages (Fig. 2) [17, 1].

The Brent Group is the top of the pre-rift sequence of the Jurassic rifting phase [18]. However, other workers have reported that an extension commenced in places during the Bajocian and involved the upper parts of the Brent Group [19, 20]. Increased rates of fault-related subsidence occurred during the Late Aelenian-Early Bajocian and affect the Viking graben and its flanking terraces. This is indicated by an increase in thickness of the lower Brent Group (with respect to the Dunlin Group) observed on each fault-blocks/half grabens as well as across block-bounding extensional faults [3].

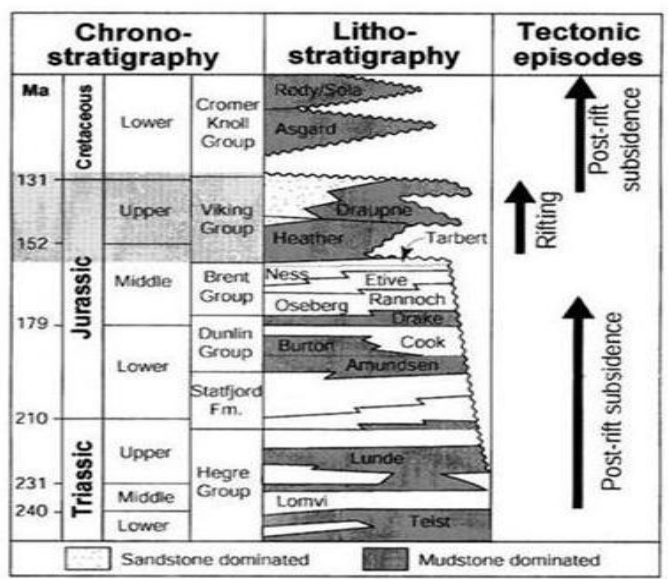

Fig. 2 - North Sea stratigraphy illustrating the studied synrift interval (Dahl and Solli, 1993). 
The chronostratigraphic interval of the main rift (synrift) stage of evolution of the northern North Sea Sedimentary Basin is the focus of the present study. The main rift stage commenced in the Late Bajocian to Bathonian when sediment supply balanced created accommodation and with the consequent deposition of the sand-prone Talbert and mud-prone Heather Formation rift wedges [21].The clay prone Draupne Formation resulted from increased extension and rotation in Oxfordian-Volgian when the deeper parts of the basin experienced increased bathymetry [13]. The upper Heather member deposition in the Late Oxfordian occurred at a time east dipping faults within the basin were dormant. The west dipping faults in the basin remained active throughout the rifting episode and experienced significant Late Jurassic footwall uplift. Symmetrical segment of the Viking Graben characterized by much palaeowater-depth was host to the Draupne Formation. The Draupne Formation is slightly wedged and thickens to the east in an opposite direction to the Heather Formation [21].

There are four discrete stages of synrift sedimentation in the Norwegian North Sea that are intimately related to the propagation, interaction and linkage of normal fault arrays [22]. Earliest in the rifting stage, many of fault segments nucleated with slow slip rates, with sediment supply outpacing tectonic subsidence and rising eustatic sea level primarily controls sedimentation. As rifting progressed, movement localized on a smaller number of active faults that experience increased displacement rates. The basin developed a graben-like geometry, and the lateral propagation and linkage of fault strands controlled accommodation generation. Although flooding of the basin occurred, sediment supply kept pace with fault-controlled subsidence. The last two stages of rifting consist of a fully linked half-graben bounding fault and the rate of sediment supply was greatly surpassed by the rate of tectonic subsidence.

The post-rift evolutionary stage of the Norwegian North Sea Sedimentary Basin occurred after the PermoTriassic extension with the deposition of the Middle Triassic to Lower-Middle Jurassic strata [1]. Several studies show that when the Middle Jurassic stretching started, the basin system had not attained a thermal equilibrium state, implying that thermal subsidence and active stretching occurred simultaneously $[23,16]$.

\section{Materials and Methods}

The data set consists of 3-D seismic subsurface survey around the Oseberg-Brage in the Norwegian northern North Sea. The study area is about 380 square kilometres and the line spacing of the survey is $12.5 \mathrm{~m}$ for both NNW-SSE oriented in-lines and NNE-SSW oriented cross-lines. The seismic data has a vertical axis in milliseconds (ms) two-way travel time (TWTT) and have not been depth converted. In order to constrain the interaction between synrift stratigraphy and normal fault growth in the Brage area, the research focussed on the synrift stratigraphy that is between the depths of 2200-2780 ms TWTT. This interval extends from the top Brent Group to the base Cretaceous seismic marker.

The first part of this approach entails mapping surfaces of discontinuities defined by onlap, toplap and erosional truncations and, care was taking to track offset horizons across faults. The mapping of seismic horizons was at trace positions that tied most closely to formation tops. Thickness variation within seismically defined synrift horizons is analysed to constrain the effect of growth of the Brage fault on synrift stratigraphy.

\subsection{Seismic Stratigraphy}

\section{Results and Discussion}

On the basis of reflection character and terminations, five regionally significant surfaces are mapped, and these include top Brent unit (top pre-rift), top lower Heather unit, top upper Heather unit, top lower Draupne unit and top upper Draupne unit (top synrift) (Figs. 3, 4, 5). A very high-amplitude reflection that is continuous throughout the seismic section characterizes the top Brent seismic unit. This reflection is a marked seismic onlap surface observed at $2450 \mathrm{~ms}$ TWTT and separates the high amplitude, sub parallel reflections of the pre-rift from the more complex seismic wedge packages of the synrift; hence it is the top pre-rift in the study area (Figs. $3,4)$.

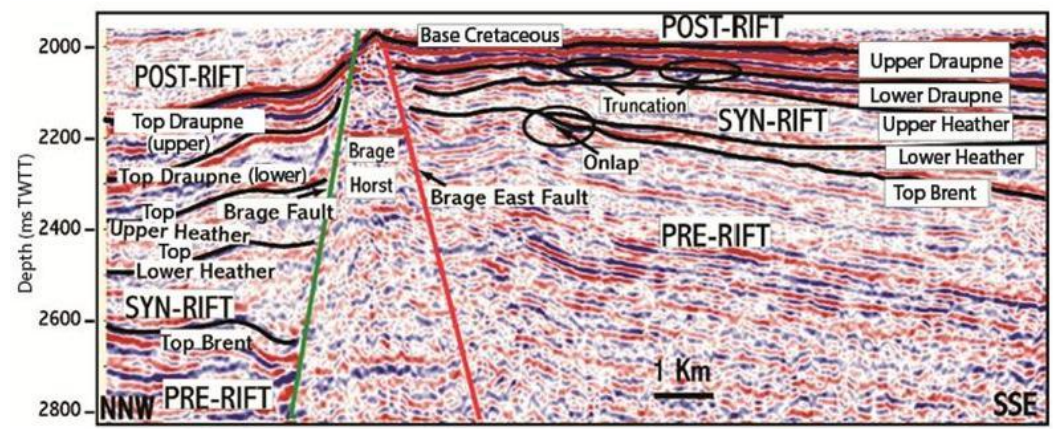

Fig. 3 - Interpreted cross section of inline 1853 showing the Brage Horst and associated faults. Note the onlap and truncation of synrift reflections. 


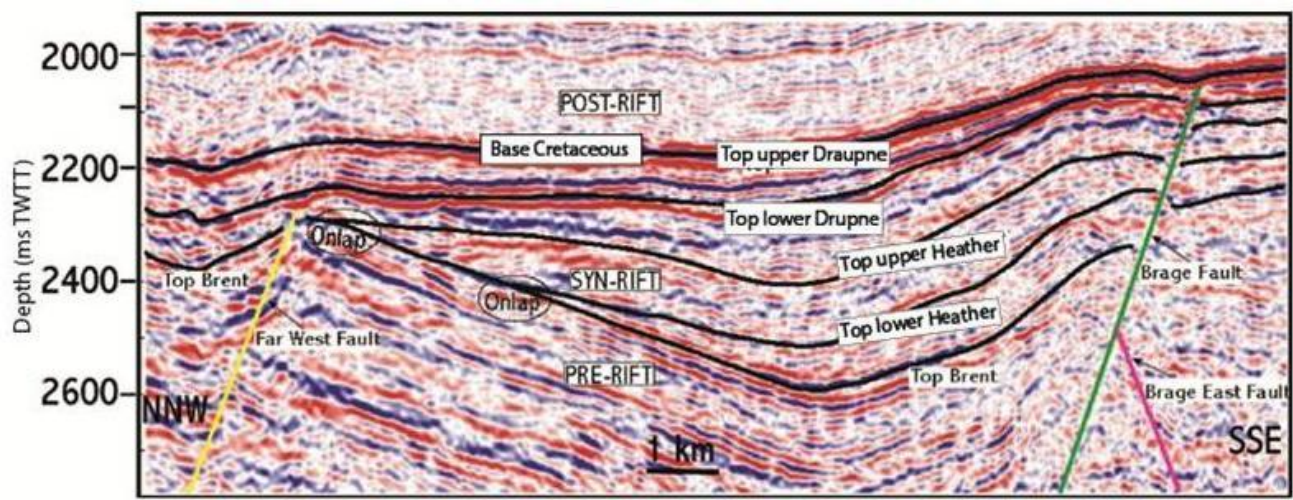

Fig. 4 - Interpreted cross section of inline showing Brage fault and other intrabasinal faults [25].

Seismic reflection of moderate-high amplitude and good continuity characterises the top lower Heather unit. This reflection is the first prominent onlap on the top Brent observed at 2450 ms TWTT (Figs. 3, 4), and this represents the boundary between the Brent Group and the overlying Viking or Humber Group. In the hangingwall of the Brage East fault, the top lower Heather unit, locally onlaps the top Brent unit at $2150 \mathrm{~ms}$ TWTT (Fig. 3). Moderate amplitude reflections that characterise the top Upper Heather seismic unit are poorly continuous. The top lower Draupne is a low to moderate-amplitude reflection characterized by good continuity. The top lower Draupne locally truncates strong synrift reflections in the hanging-wall of the Brage East fault at $2050 \mathrm{~ms}$ TWTT (Fig. 3). The top of the synrift mapped as top upper Draupne (base Cretaceous) in the Brage area is marked by very high-amplitude reflection that is excellently continuous throughout the seismic section (Figs. 3, 4, 5). The strong reflection is as a result of the sharp impedance contrast between the carbonates in the lower part of the postrift Cromerknoll Group and the underlying synrift Draupne Formation [24].
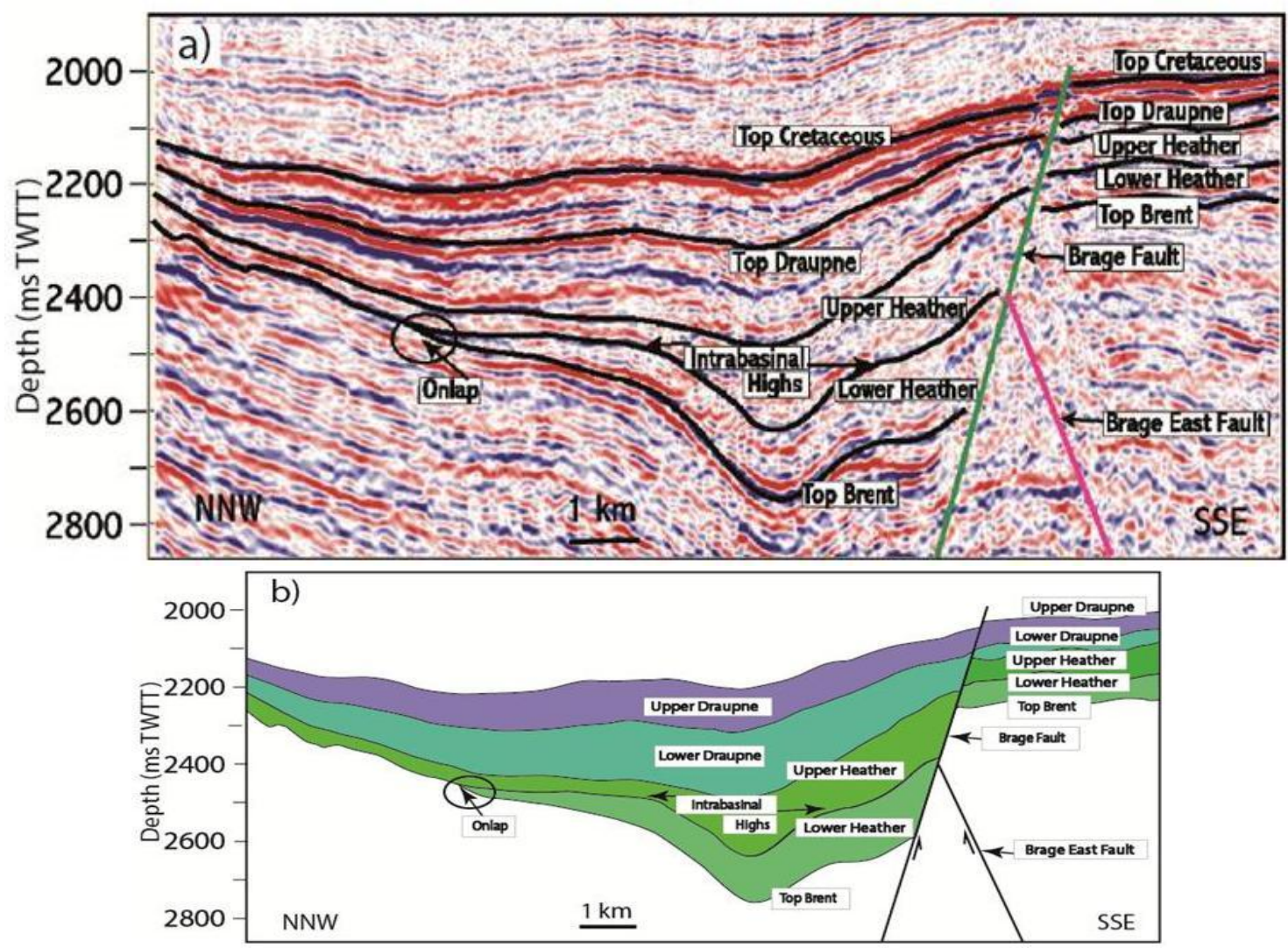

Fig. 5 - (a) Interpreted seismic inline 1529, and (b) Drawing of interpretations showing the wedge-like geometry of synrift seismic stratigraphic units. 


\subsection{Tectono-stratigraphic evolution of the Brage Fault Zone}

The study of the Brage fault zone evolution and the response of synrift stratigraphy to the fault growth and linkage were undertaken by integrating stratigraphic data in the present study with structural data documented by [25].

\subsubsection{Brage Fault Zone Evolution from Analysis of Lower and Upper Heather Seismic Units}

Pronounced thickening and large-scale wedge-like geometry characterise the lower Heather seismic unit (Figs. $3,4,5)$ which suggest that this unit deposited after the beginning of rifting in the Late Bajocian. Assuming that stratal thickening serves as a proxy for subsidence, this may suggest that the lower Heather unit deposited following enhanced subsidence of the sub-basins next to the Brage fault. The lower Heather and upper Heather seismic units are distinctly wedge-shaped in cross sections (Figs. 3, 4, 5). The wedge geometry that characterized the seismic units is typical of surface breaking faults in which sequences expand and diverge in towards the fault zone. The wedge-like geometry that is more pronounced with the Heather unit than the Draupne seismic unit relates to a decrease in the displacement rate along strike from the centre towards the tips of the fault segments in the early stages of rifting. In the Brage area, the overall wedge-shaped geometry is disrupted by activity of the Far West intra-hanging-wall fault (Fig. 4). The Brage fault occurs with real thickening in the Heather seismic unit (Figs. 3, 4, 5). This indicates that the Brage fault was much more active than the Far West fault and the Brage East fault. In addition, it shows that enhanced subsidence in the sub-basin next to the Brage fault occurred in the Heather time.

The isochron map for the lower Heather (Fig. 6) illustrates at least six depocentres that exerts primary control on the lower Heather unit deposition, suggesting a time when displacement along fault strike was highly variable. The lower Heather seismic unit was also observed to onlap on intrabasin high, which suggest that the highs have a positive expression during the lower Heather unit deposition. The onlap on the intrabasin highs and the lower Heather unit absence above some of the highs suggest a relatively low deposition initially occurred above them. The highs formed as a result of low displacement on the Brage fault, and they represent fault segment tips. It is also observed that isochron thick regions occurs against the Brage fault and the Far West fault, and are separated by thinner regions that correspond to intrabasin highs (Fig. 6). The pattern of occurrence of the depocentres suggests that the controlling fault strands were surface breaking faults during the lower Heather unit deposition, with most subsidence in the immediate hanging-wall of the faults.

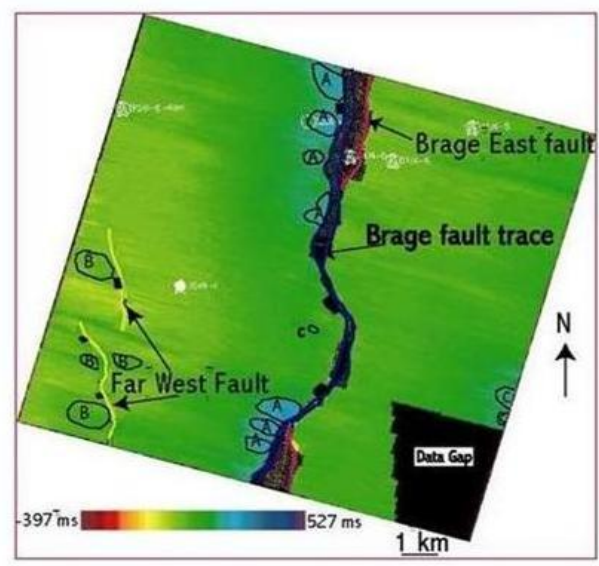

Fig. 6 - Isochron map of the lower Heather unit. Note the distribution of the small isolated depocentres (labelled A, B, C) with respect to fault traces.

The upper Heather seismic unit also shows onlap in the hanging-wall of the Brage fault (Figs. 4, 5). The top of the upper Heather seismic unit exhibits divergent internal seismic geometry in the crest of the Far West fault (Fig. 4), and this suggests it deposited following an increase in the rate of extension. Both the lower and upper Heather seismic units characteristically thickens towards the Brage fault, a sign that their deposition was fault controlled and that the extensional activity was more on the fault than other intrabasinal faults in the study area. The isochron map for the upper Heather seismic unit illustrates three main depocentres that exert primary control on the character and deposition of the Unit (Fig. 7). The thick that mark the isochron map of the upper Heather unit are wider than those observed at lower Heather level which show a later time of deposition when variation in displacement along fault strike is more uniform. The hanging-wall thicknesses of the lower Heatherand upper Heather seismic units are greater than their footwall thickness, and this suggests that the sedimentation rate is slightly higher than the displacement rate as at Heather seismic unit deposition. 


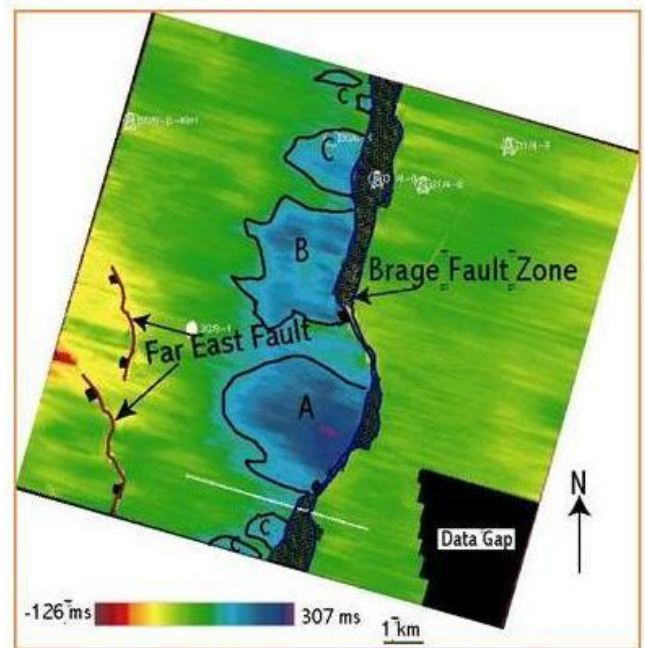

Fig. 7 - Isochron map of the upper Heather seismic unit. Note how the depocentres adjoined to the Brage fault have broadened width compared with depocentres at lower Heather unit. A, B, and C represent depocentres.

\subsubsection{Fault Zone Evolution from Analysis ofDraupne Seismic Unit}

Analysis of the isochron (thickness) map for the lower Draupne seismic unit illustrates three main fault adjacent depocentres that control the seismic characteristic and deposition of the Unit (Fig. 8). Two of these depocentres located next to the Brage fault represents two fault strands. The third major depocentre occurs adjacent the Far West fault. These observations suggest that as at the time of the lower Draupne unit deposition, subsidence was less variable along fault strike than it was at Heather unit's level. Consequently, a more open and continuous hanging-wall depocentres developed as more uniform accommodation develop along strike after the evolution of a major throughgoing fault zone. The thickness map for the lower Draupne unit suggests a growth stage that consists of two main overlapping fault segments. At the Draupne seismic unit level, diverged reflections in the crest of the Far West fault are somewhat reduced, and this may show insignificant subsidence (Fig. 4).

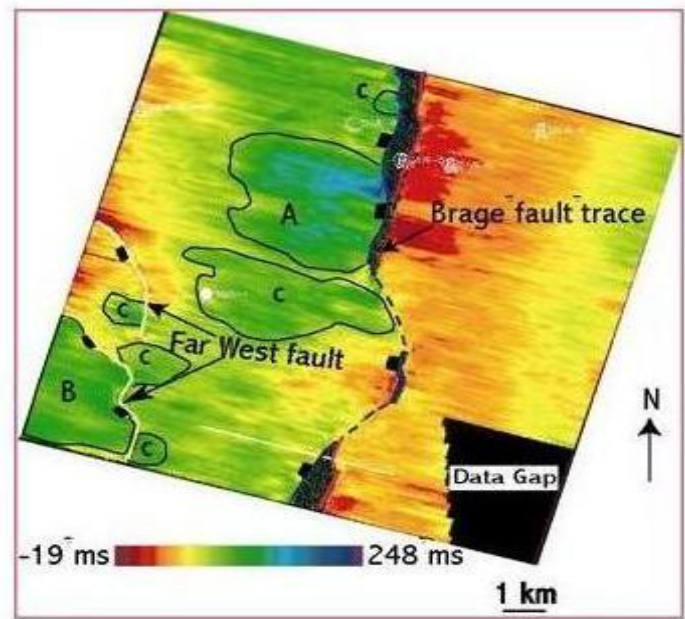

Fig. 8 -Isochron map of the lower Draupne unit. Note how created accommodation has become more uniformly distributed along fault strike. Dashed fault trace mark areas of no offset. $A$, B, and $C$ represent depocentres.

The upper Draupne unit is also characterised by thickness variation as is typical of the synrift packages. Fewer but larger fault proximal thick (A, B, and C) developed at upper Draupne resulting in uniformly distributed accommodation along fault strike and a more open continuous hanging-wall depocentre (Fig. 9). A three-dimensional view of the top upper Draupne (base Cretaceous) surface shows a general dip from east to west (Fig. 10). This topography corresponds to the topography of the basin at the end of rifting and suggests that the basin is slightly under-filled. 


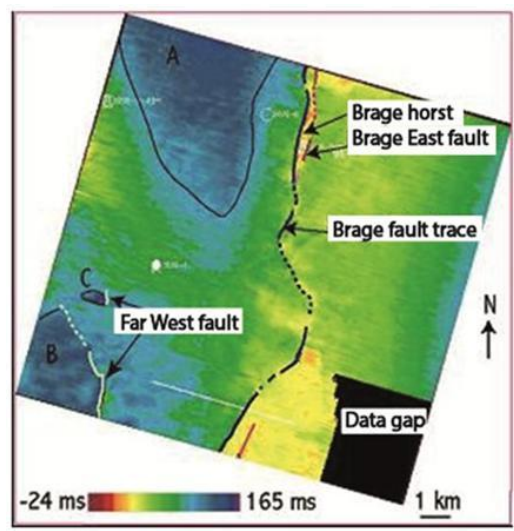

Fig. 9 -Isochron map of the upper Draupne unit. Note the uniformly distributed accommodation along fault strike and the development of a more open continuous hanging-wall depocentre. $\mathrm{A}, \mathrm{B}$, and $\mathrm{C}$ are depocentres.

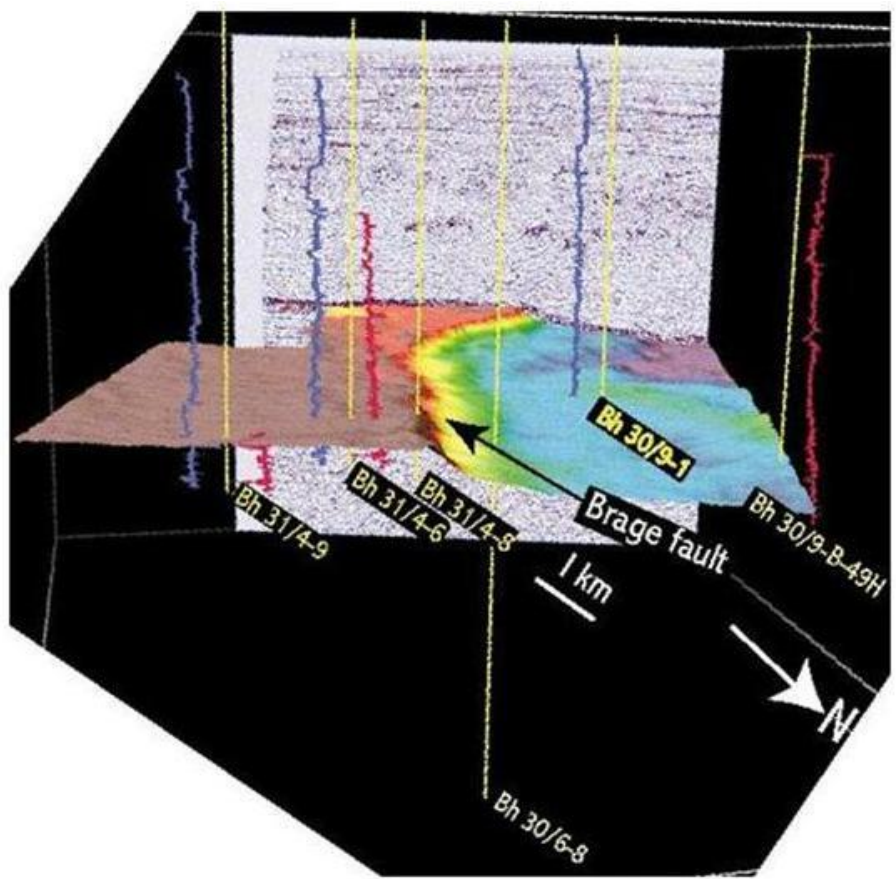

Fig. 10 - 3-D view of the top upper Draupne horizon offset by the Brage fault. $B h=$ boreholes drilled into footwall and hanging-wall. Note the general dip from east to west of the present day topography.

\subsubsection{Isolated Fault Strands and Segment Linkage}

The isolated fault strands stage represents the fault growth stage during the lower Heather unit deposition typified by a large number of isolated small depocentres (interpreted as small fault segments). This stage of the Brage fault zone evolution entails the nucleation and propagation of each isolated fault strands and span from Middle Bathonian-Middle Oxfordian corresponding to the time interval of about $5 \mathrm{Ma}$ based on the time scale of [26]. When the results of the thickness distribution analysis in the present study is buttressed with the Brage fault geometric structure and displacement characteristics documented by [25], at least six small isolated fault segments nucleated and propagated during this stage (Fig. 11a). The growth and interaction of these segments control the stratigraphic architecture and distribution of the lower Heather seismic unit, with sedimentation occurring in structurally controlled topographic lows. [25] also recorded that the Brage fault is about $21 \mathrm{~km}$ in strike length and with a displacement that is up to $610 \mathrm{~ms}$ TWTT. He also established the lengths of the Brage fault segments at top Brent level as $5.6 \mathrm{~km}$ (segment A), $3.9 \mathrm{~km}$ (segment B), $5 \mathrm{~km}$ (segment C), $6.7 \mathrm{~km}$ (segment D); whilst the lengths of geometric segments at top Draupne level are $5.6 \mathrm{~km}$ (segment A), $4 \mathrm{~km}$ (segment B), $5 \mathrm{~km}$ (segment C), and $1.5 \mathrm{~km}$ (segment D). A plausible explanation for this observation is that the fault segment lengths are near constant from an early stage of rifting. Furthermore, the greatest displacement of $610 \mathrm{~ms}$ TWTT is lower than would be predicted for a $21 \mathrm{~km}$ long fault using the displacement-length scaling relationship $(\mathrm{Dmax}=0.03 \mathrm{~L} 1.06)$ introduced by [27]. This suggests the Brage fault is structurally immature 
which result from a possible cessation of extensional activity on the fault before it grew to keep up a proportionate displacement-length relationship.

The growth process involved early attainment of fault length and later interaction between fault strands retards lateral propagation producing near constant lengths for the entire process of the fault growth. Further fault growth occurs by increase in cumulative displacement [e.g. 28, 29, 30].Some of the fault strands break surface at the Heather unit level, which resulted in a significant thickening of the unit. The monocline structures observed above the faults shows that some of the fault strands were blind faults for the most part of this stage. The boundaries of these segments are mark by intrabasin topographic highs separated by topographic lows and these are transverse fault-related anticlines and synclines associated with along strike displacement gradients. Fault segments interaction continued into the Draupne seismic unit level, and the segments later linked to form the present-day Brage fault length (Fig. 11b).

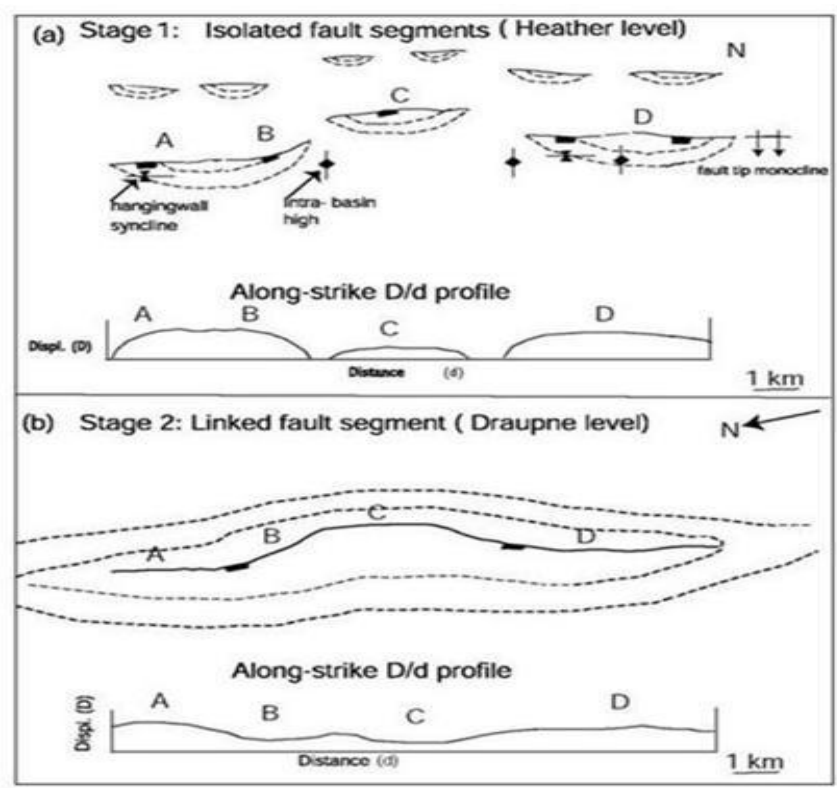

Fig. 11 - Schematic structural evolution of the Brage fault zone by integrating stratigraphy of the fault zone with the structural and D-d characteristics documented by [25]. Note the isolated and linked fault segments in (a) and the fully developed fault system following segments interactions and linkage in (b).

Isochron map for the lower Draupne seismic unit illustrates three fault strands (as a result of segment linkage at Heather time) that interacted to control the Draupne seismic unit deposition. The growth process at this level, continued from Middle Oxfordian to Middle Ryazanian, representing a time interval of about 14 Ma based on the timescale of [26]. Divergent seismic reflections of the lower Draupne seismic unit occur at the crest of the Far West fault which suggests that the fault was a surface-breaking feature at this time (Fig. 4). Reflections at the base of the lower Draupne seismic unit have divergent internal seismic geometries in the crest of the Far West fault, thus suggesting that the fault was a surface breaking feature at this time. By upper Draupne level which is Cretaceous in age, after a major throughgoing fault zone developed, the two depocentres identified on the isochron map for the lower Draupne seismic unit merged to form a more open and continuous hanging-wall depocentre as a result of a more uniform accommodation created along fault strike (Fig. 8).The Brage East fault and the Far West fault stay intermittently active and show alternating activity with the evolving Brage fault (since these faults locally offset the top upper Draupne).

The isochron maps generated for the seismic stratigraphic units illustrate a hierarchy of fault-parallel isolated depocentres. The depocentres occur near the Brage fault and the Far West fault in the hanging wall (Figs. 6-9), and as such their occurrence relates to variations in displacement that accumulated along each fault segment before linkage. The positions of greatest displacement associated with the depocentres are near fault segments centre and the displacement decreases towards the intrabasin highs. A comparative analysis of the isochron map produced for the lower Heather, upper Heather, upper Draupne and lower Draupne seismic units (Figs. 6-9), suggest a more open and continuous hanging-wall depocentre with more uniform accommodation created along strike at top lower Draupne and top upper Draupne level. This is as a result of a major throughgoing Brage fault zone that develops. 


\section{Conclusion}

This study shows that the evolution of the Brage fault is by the nucleation and propagation of at least six small normal fault segments that linked to form the full-length basin-bounding fault. The entire growth process consists of an early stage when small isolated normal fault segments nucleated and began to interact between Middle Bathonian-Callovian times. By Middle Oxfordian, during the deposition of the upper Heather seismic unit, three segments labelled A, B, and D had resulted from the soft linkage of six fault segments that propagate from both north and south of the study area. At Draupne level, these segments hard linked with a central splay fault (labelled C), thus forming a jog or major bend in the Brage fault trace and a full length Brage fault zone that is a surface breaking feature developed after the breaching of the relay ramp. The basin-ward dip of hanging-wall reflections immediately next to the fault segments supports vertical propagation from depth as well as lateral propagation through linkage.

The lower Heather, upper Heather, and Draupne seismic units are distinctly wedge-shaped in cross sections (Figs. 3, 4, 5). The wedge geometry that characterized the seismic units is typical of surface breaking faults in which sequences expand and diverge in towards the fault zone. The wedge-like geometry that is more pronounced with the Heather unit than the Draupne seismic unit relates to a decrease in the displacement rate along strike from the centre towards the tips of the fault segments in the early stages of rifting. The growth process of the Far West intra-hanging-wall fault affects the overall wedge-shaped geometry of synrift stratigraphic units (Fig. 4). The Brage fault occurs with real thickening in the Heather seismic unit (Figs. 3, 4, 5). This indicates that the Brage fault was much more active than the Far West fault and the Brage East fault. In addition, it shows that enhanced subsidence in the sub-basin next to the Brage fault occurred in the Heather time.

It is construe that the Brage fault is structurally immature as a result of a possible cessation in extensional activity on the fault before it grew to keep up a proportionate displacement-length relationship.

\section{Acknowledgement}

The author is grateful to Schlumberger for providing the interpretation package use in this study. The seismic data provided by Statoil is highly appreciated.

\section{References}

[1] Faerseth, R. B. (1996). Interaction of Permo-Triassic and Jurassic extensional fault-blocks during the development of the northern North Sea. Geological Society of London, vol. 153, pp. 931-944.

[2] Steel, R. J., and Ryseth, A. (1990). The Triassic-early Jurassic succession in the northern North Sea: Megasequence stratigraphy and intra-Triassic tectonics. In R. P. F. Hardman, and J. Brooks (Eds.), Tectonic events responsible for Britain's oil and gas reserves. Geological Society Special Publication, vol. 55, pp. 139-168.

[3] Steel, R. J. (1993). Triassic-Jurassic megasequence stratigraphy in the Northern North Sea: rift to post-rift evolution. In J. R. Parker (Ed.), Petroleum Geology of Northwest Europe, Proceedings of the 4th Conference.Geological Society London, pp. 299-315.

[4] Roberts, A. M., Yielding, G., Kusznir, N. J., Walker, I. M., and DornLopez, D. (1995). Quantitative analysis of Triassic extension in the northern Viking Graben. Geological Society of London, vol. 152, pp. 15-26.

[5] Morley, C. K. (1999). Patterns of displacement along large normal faults: implications for basin evolution and fault propagation, based on examples from East Africa. America. Association of Petroleum Geologists Bulletin, vol. 83, pp. 613-634.

[6] Gawthorpe, R. L., and Leeder, M. R. (2000). Tectono-sedimentary evolution of active extensional basins. Basin Research, vol. 12, pp. $195-218$

[7] Morley, C. K. (2002). Evolution of large normal faults: evidence from seismic reflection data. America Association Petroleum Geologists Bulletin, vol. 86, no. 6, pp. 961-978.

[8] Leeder, M. R., and Gawthorpe, R. L. (1987). Sedimentary models for extensional tilt-block/half-graben basins. In M. P. Coward, J. F. Dewey, and P. L. Hancock (Eds.), Continental extensional tectonics. Geological Society Special Publication, vol. 28, pp. 139152.

[9] Schlische, R. W. (1991). Half-graben basin filling models: new constraints on continental extensional basin development. Basin Research, vol. 3, pp. 123-141.

[10] Gawthorpe, R. L., Fraser, A. J., and Collier, R. E. L. (1994). Sequence stratigraphy in active extensional basins: implications for the interpretation of ancient basin fill. Marine and. Petroleum Geology, vol. 11, pp. 642-658.

[11] Dawers, N. H., and Underhill, J. R. (2000). The role of fault interaction and linkage in controlling synrift stratigraphic sequences: Late Jurassic, Stratfjord East area, northern North Sea. America Association of Petroleum Geologists Bulletin, vol. 84, pp. 45-64.

[12] Ravnas, R., and Bondevik, W. (1997). Architecture and controls on Bathonian-Kimmeridgian shallow-marine synrift wedges of the Oseberg-Brage area, northern North Sea. Basin Research, vol. 9, pp. 197-226.

[13] Faerseth, R. B., and Ravnas, R. (1998). Evolution of the Oseberg fault-block in context of the northern North Sea structural framework. Marine and Petroleum Geology, vol. 15, pp. 467-490.

[14] Schlische, R. W., and Anders, M. H. (1996). Stratigraphic effects and tectonic implications of the growth of normal faults and extensional basins. In K. K. Beraton (Ed.), Reconstructing the history of Basin and Range extension using sedimentology and stratigraphy. Geological Society of America Special Papers, vol. 303, pp. 183-203.

[15] Dawers, N. H., Berge, A. M., Hager, K. O., Puigdefabregas, C., and Underhill, J. R. (1999). Controls on Late Jurassic, subtle sand distribution in the Tampen Spur area, northern North Sea. In A. Fleet, and S. A. R. Boldy (Editors.), Petroleum Geology of Northwest Europe Petroleum Geology of NW Europe, Proceedings of the 5th Conference. Geological Society of London, pp. 827838

[16] Roberts, A. M., Yielding, G., Kusznir, N. J., Walker, I. M., and DornLopez, D. (1993). Mesozoic extension in the North Sea: constraints from flexural backstripping, forward modeling and fault population. In J. R. Parker (Ed.), Petroleum Geology of Northwest Europe, Proceedings of the 4th Conference. Geological Society of London, pp. 1123-1136. 
[17] Dahl, N., and Solli, T. (1993). The structural evolution of the Snorre field and surrounding areas. In J. R. Parker (Ed.), Petroleum Geology of Northwest Europe, Proceedings of the 4th Conference. Geological Society of London, pp. 1159-1166.

[18] Yielding, G., Badley, M. E., and Roberts, A. M. (1992). The structural evolution of the Brent Province. In A. C. Morton, R. S. Hazeldine, M. R. Giles, and S Brown (Eds.), Geology of the Brent Group. Geological Society Special Publication, vol. 71, pp. 3566.

[19] Helland-Hansen, W., Ashton, M., Lomo, L., and Steel, R. (1992). Advance and retreat of the Brent delta: Recent contributions to the deposition model. In A. C. Morton, R. S. Haszeldine, M. R. Giles, and S. Brown (Eds.), Geology of the Brent Group. Geological Society Special Publication, vol. 61, pp. 109-127.

[20] Johannessen, E. P., Mjos, R., Renshaw, D., Dallrd, A., and Jacobsen, T. (1995). Northern limit of the 'Brent delta at the Tampen Spur: a sequence stratigraphic approach for sandstone prediction. In R. J. Steel, V. Felt, E. P. Johannessen, and C. Mathieu (Eds.), Sequence stratigraphy of the northwest European margin. Norwegian Petroleum Society Special Publication, vol. 5, pp. 213-256.

[21] Faerseth, R. B., Knudsen, B. E., Liljedahl, T., Midboe, P. S., and Soderstrom, B. (1997). Oblique rifting and sequential faulting in the Jurassic development of the northern North Sea. Journal of Structural Geology, vol. 19, pp. 1285-1302.

[22] McLeod, A. E., Underhill, J. R., Davies, S. J., and Dawers, N. H. (2002). The influence of fault array evolution on synrift sedimentation patterns: controls on the deposition in the Strathspey-Brent-Stratfjord half-graben, northern North Sea. America Association of Petroleum Geologists Bulletin, vol. 8, no. 6, pp. 1061-1093.

[23] Gabrielsen, R. H., Faerseth, R. B., Steel, R. J., Idil, S., and Klovjan, O. S. (1990). Architectural styles of basin fill in the northern Viking Graben. In D. J. Blundell, and A. D. Gibbs (Eds.), Tectonic Evolution of the North Sea Rifts (pp. 158-179). Oxford: Clarendon Press.

[24] Davies, S. J., Dawers, N. H., McLeod, A. E., and Underhill, J. R. (2000). The structural and sedimentological evolution of early synrift successions: the Middle Jurassic Tarbert Formation, North Sea. Basin Research, vol. 12, pp. 343-365.

[25] Adiotomre, E. E. (2002). Structural and stratigraphic evolution of the Brage area Norwegian North Sea, masters diss., University of Manchester, United Kingdom.

[26] Gradstein, F. M., Agterberg, F. P., Ogg, J. G., Hardenbol, J., Van Veen, P., Thierry, J., and Huang, Z. (1994). A Mesozoic time scale. Journal of Geophysical Research, vol. 99, pp. 24051-24074.

[27] Schlische, R. W., Young, S. S., Ackermann, R. V., and Gupta, A. (1996). Geometry and scaling relations of a population of very small rift-related normal faults. Geology, vol. 23, pp. 683-686.

[28] Dawers, N. H., and Anders, M. H. (1995). Displacement-length scaling and fault linkage. Journal Structural Geology, vol. 17, pp. 607-614.

[29] Cartwright, J. A., Trudgill, B. D., and Mansfield, C. S. (1995). Fault growth by segment linkage: an explanation for scatter in maximum displacement and trace length data from the Canyonlands Graben of S. E. Utah. Journal of Structural Geology, vol. 17, pp. 1319-1326.

[30] Walsh, J. J., Nicol, A., and Childs, C. (2002). An alternative model for the growth of faults. Journal of Structural Geology, vol. 24, pp. 1669-1675. 